\title{
Contribution to the knowledge of early geotechnics during the twentieth century: Ralph Peck
}

\author{
Antonio Lara-Galera, Rubén Galindo-Aires, and Gonzalo Guillán-Llorente \\ Civil Engineering and Construction Department, Universidad Politécnica de Madrid, Madrid, Spain \\ Correspondence: Antonio Lara-Galera (alargal@ciccp.es)
}

Received: 5 November 2018 - Accepted: 14 January 2019 - Published: 11 February 2019

\begin{abstract}
Ralph B. Peck (1912-2008), graduate and doctor of philosophy in civil engineering (1934 and 1937 respectively) from the Rensselaer Polytechnic Institute, was one of the major contributors to the development of geotechnics in the twentieth century. Born in Winnipeg (Manitoba) as an American national, he was influenced from childhood by the world of civil engineering through his father, Orwin K. Peck, who was a civil engineer, mainly as a structural engineer in the railway sector.

In the absence of job offers as a structural engineer, Ralph Peck arrived at Harvard University in 1938 to attend the soil mechanics courses taught by Arthur Casagrande, which guided Peck's professional career towards geotechnics. In addition to Casagrande, Peck had the opportunity to meet and work with other very important people related to geotechnics: Albert E. Cummings, Laurits Bjerrum, Alec W. Skempton and especially Karl Terzaghi, with whom he established a great friendship, in addition to providing support, professional advice and performing important work, such as the Chicago Subway Works.

Peck actively dedicated himself to consulting work, which led him to visit 44 states within the United States and 28 countries on five continents. In addition, he also participated in research work where he was asked and was a committed lecturer at the University of Illinois, where he was a professor for 32 years.

The objective of this paper is to analyse, through Peck's biography, his contribution to the field of geotechnics based on his research, teaching and consultancy work, and through the influence of Peck on other important people in the field, such as Karl Terzaghi.
\end{abstract}

\section{Origins}

Ralph Brazelton Peck (Winnipeg, Manitoba, 23 June 1912; Albuquerque, New Mexico, 18 February 2008) was the son of Orwin K. Peck and Ethel Huyck Truby, both from South Dakota. Both Orwin and Ethel studied at the University of Dakota (currently Wesleyan University). Later, Ethel completed her teaching studies at the University of Minnesota and Orwin graduated at the end of 1907 in engineering from the University of Wisconsin.

Ralph's father developed his professional career with several railroad companies in the field of civil engineering, working mainly on the design of railway bridges during the expansion of the Great Pacific Railway Corridor (Grand Truck Pacific Railway) in Canada. In 1921 Orwin Peck joined the Denver \& Rio Grande Western Railways Company in Denver and in 1939 as a bridge engineer, he was promoted to structures engineer, remaining with the same company until retirement in 1956 at the age of 75 years.

Due to the work of Orwin, Ralph was born in Canada. In spite of this, he is considered American because his parents were American citizens. In addition, the Peck family had to change their home several times also because of the work of Orwin: they moved from Canada to Louisville (Kentucky), then to Detroit and, finally, in 1923, to Denver (Colorado) where they settled.

In his youth, Ralph was a sickly boy, especially affected by flu, diphtheria and scarlet fever. This resulted in Ethel often staying at home, which quickly resulted in having to take charge of Ralph's education thanks to her experience as a teacher. When he was a child, Ralph Peck wanted to be a tram driver, but his father managed to influence him to become an engineer. 
Peck's parents were active practitioners of the Denver Presbyterian Church, which surely influenced Ralph's social life during his youth to focus on Christian groups. It was in these groups where he met Marjorie Elizabeth Truby, who would later become his wife.

\section{Rensselaer Polytechnic Institute (RPI)}

On 5 September 1930, when Ralph was 18 years old, he turned down two scholarships, one for the University of Colorado and another for the Colorado School of Mines, to finally join the Rensselaer Polytechnic Institute (RPI) in Troy, New York (the RPI is a private institution that was founded in 1824, and is the Americas' oldest technological research university). Just before he started his university studies, during the summer of 1930, Ralph was working at the Denver \& Rio Grande Railroad Company, in a group of workers carrying out works on train tracks.

It was not a coincidence that Peck went to study at the Rensselaer Polytechnic Institute. His father knew that the best bridge engineers in all of the United States had studied at the RPI, which at that time was a university exclusively for men. The main problem for Ralph was the long distance between Denver and New York, but because Orwin Peck had free passes to the railroad thanks to his work in the sector, including a trip every Christmas, Ralph could study in New York.

Throughout his university period, Ralph took advantage of the summer vacation to perform the obligatory practices within his study programme. So, Peck split 12-week compulsory topography practices into two 6-week groups, conducting a practice group during the summer of 1931 and the other in the summer of 1932. During that same period, Peck also had to write two reports of certain works, for which he chose the Cheesman Dam and the Denver Water Department.

The Cheesman Dam is a cyclopean masonry gravity dam $87.17 \mathrm{~m}$ high which is located in Douglas County, Colorado (Nicolau and Puig de la Bellacasa, 1909).

Still at university, Peck conducted the project of his first bridge for the Rio Grande Railroad. The project was carried out during the Christmas holidays of his last academic year, in December 1930. In particular, the project was for a bridge with beams of $20 \mathrm{~m}$ span over the Animas River, near Aztec, New Mexico. The bridge was built within the mentioned period, but it was razed a few years later due to a strong flood of the Animas River.

In 1934 Ralph Peck obtained his civil engineering degree at 22 years old. Due to the still-present consequences of the Great Depression of 1929, Peck was unable to find work after completing his engineering studies, so he accepted a 3year scholarship at the RPI for postgraduate studies in structures, mathematics and geology. His thesis "stiffness in suspension bridges" was reviewed by renowned bridge engineer
David Barnard Steinman ${ }^{1}$, resulting in Peck receiving his PhD in civil engineering on 14 June 1937 from the Rensselaer Polytechnic Institute in Troy, New York.

On 14 June 1937, the year he earned his doctorate, Peck married Marjorie Truby at the second Presbyterian Church of Troy. For her part, Marjorie graduated in chemistry in June 1936 at the University of Denver, and after her graduation she worked as a laboratory technician at the Denver General Hospital.

After obtaining his doctorate and influenced by his father, Peck enrolled in a 6-week course taught by the American Company of Bridges in Ambridge, Pennsylvania, with whom he began to work after the summer of 1937. Seven months later in March 1938, he had to quit his job because the company had no projects.

\section{First influences on soil mechanics}

\subsection{Harvard University: Arthur Casagrande}

Once again Peck was made unemployed in March 1938, and he received no job offers because of the tail end of the Depression.

As he continued his search for a job, Ralph wrote to Linton Elias Grinter, engineer and dean of the Armour Institute of Technology ${ }^{2}$, Chicago, asking for a position as a lecturer. Although there were no vacancies, Grinter informed him that he could have a job if he learned soil mechanics and foundation engineering. In an inspired decision, Ralph borrowed USD 5000 from his father-in-law to enroll at Harvard University and thus acquired the necessary qualification for the Armour Institute position.

In March 1938, Ralph Peck wrote to Arthur Casagrande requesting to be admitted as soon as possible to Harvard University. In the first instance, Casagrande responded to Peck asking him to wait until the next academic year, but because of Peck's insistence, Casagrande accepted his proposal and Peck joined his classes as a listener, thus avoiding all administrative restrictions. Accordingly, Ralph Peck arrived at Harvard University in April of the 1937-1938 academic year, joining the programme taught by Arthur Casagrande during the spring semester (Hirschfeld and Poulos, 1974).

Peck managed to impress Casagrande with his structural skills, becoming laboratory assistant at Harvard University under the supervision of engineer Ralph E. Fadum, engi-

\footnotetext{
${ }^{1}$ David Barnard Steinman (New York, June 1886; Dand, August 1960). Graduated in 1906 from City College. Master of Arts from Columbia University and $\mathrm{PhD}$ in 1911 from the same University. He was engineer among others of Mackinac Bridge (19531957), the reconstruction of the Brooklyn Bridge (1948-1954) and the Kingston Bridge (1952-1956).

${ }^{2}$ The Armour Institute was created in 1893 to provide training in engineering, chemistry, architecture and librarianship. By merging with the Lewis Institute in 1940, Illinois Tech University was created.
} 


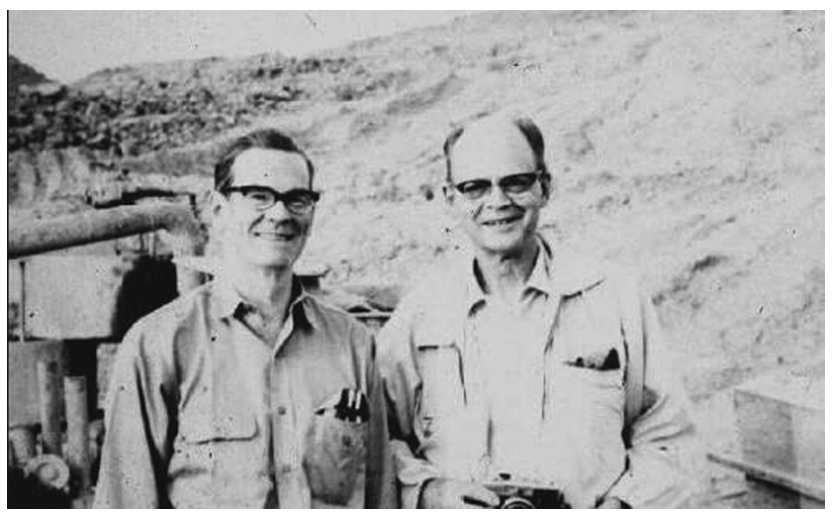

Figure 1. Ralph Peck and Arthur Casagrande. Source: Ralph B. Peck Family. All rights reserved.

neer and assistant to Casagrande, and field observer for Casagrande in his consulting work in Boston.

A significant fact of the seriousness and character of Peck is that 2 days later after writing to Casagrande he got the job opportunity he had been waiting for to work as bridge designer in the prestigious company Waddell \& Hardesty in New York, and Peck turned it down.

\subsection{Albert Edward Cummings}

Early in the professional career of Ralph Peck, one of his mentors was Albert Edward Cummings ${ }^{3}$.

Cummings was a great engineer, geotechnically selfemployed and pioneer in the foundation with piles, who worked for 40 years with the Raymond Concrete Pile Company. In his early work with Cummings, Peck said the following: "Al adopted me when I arrived in Chicago, introduced me to the engineering community and shared with me his enthusiasm for soil mechanics. Cummings was very familiar with the theoretical developments, especially those of the elasticity that could be applied to soil mechanics. He had also maintained a broad correspondence with experts in soil elasticity and mechanics, throughout the world" (Dunnicliff and Deere, 1984).

Albert Edward Cummings passed away in 1955 and bequeathed his extensive technical library to Ralph Peck.

\footnotetext{
${ }^{3}$ Albert (Al) Edward Cummings (St. Louis, Missouri, 1894; 20 July 1955). Graduated from the University of Wisconsin in 1915. Director of development of the Raymond Concrete Pile Company and member of its board of directors. Was decisive in the return of Karl Terzaghi to the United States in November of 1938 and in the works of Chicago Subway 5.
}

\subsection{Karl Terzaghi}

Ralph Peck started working as an assistant to Karl Terzaghi ${ }^{4}$ in January 1939 in the Chicago subway project (Initial System of Chicago Subways).

Terzaghi returned to the United States as an immigrant with the help of Albert Eduard Cummings and Arthur Casagrande, who guaranteed Terzaghi as an important asset for the country (Peck, 1993).

After the return of Terzaghi to the United States, Cummings offered him the possibility of giving a lecture to the local Chicago section of the American Society of Civil Engineers (ASCE), which he accepted. For his lecture, Terzaghi took advantage of the issue of irrigation of excavations in urban tunnels, generating a great deal of interest from the audience. As a result, he was offered to work as a consultant for two different clients in the Chicago Subway Project in December 1938. Terzaghi imposed a number of conditions to be able to accept the post, including sampling by Shelby tubes (they are thin-walled, hollow steel tubes, which are driven into the ground to extract a relatively undisturbed soil sample for use in laboratory tests), the implementation of a laboratory under the direction of a person chosen by himself and a salary of USD 100 a day (Dunnicliff and Deere, 1984). His terms were accepted and Terzaghi finally accepted the position.

To manage the work on the Chicago Subway Project, Terzaghi asked Arthur Casagrande to assign him someone as an on-site collaborator. Casagrande proposed Ralph Peck, who had previously been his pupil and a brilliant lab assistant at Harvard University. Thus, in January 1939 Ralph Peck left Harvard University, arriving on 14 January in Chicago to become the representative of Terzaghi in the Chicago Subway Project (earning USD 300 per month). As soon as he arrived to take charge of field observations and laboratory tests, he found that there was neither a soil laboratory nor the testing equipment that Terzaghi had demanded.

During the Chicago Subway Works, Peck was in frequent contact with Terzaghi, who asked him for numerous data of a wide variety of daily measurements, figures, schematics and typed written reports. Every month or month and a half, Terzaghi stayed for a week in Chicago to discuss Peck's results and provide him with professional advice. Among the many tests that Terzaghi asked Peck, he asked him to control the loads on the struts of the shoring excavations by using hydraulic jacks, to analyse whether the clays fulfilled the theory of the Rankine pressure for sands that he had proposed after his studies after the collapse of the Berlin subway of 1935. Rankine's theory was developed in 1857 by William John Macquorn Rankine and it is a stress field solution that predicts active and passive earth pressure.

\footnotetext{
${ }^{4}$ Karl Anton von Terzaghi Edler von Pontenuovo (Prague, Czech Republic, 2 October 1883; Winchester, Massachusetts, 25 October 1963). Graduated with honours in technical engineering from the Technical University of Graz. He is the father of soil mechanics.
} 


\subsection{Ray Knapp and Ralph Burke}

During his Chicago stage, Ralph Peck worked under Ray Knapp's supervision, who was the administrative supervisor and chief of the inspection section of the works. He was responsible for topography, the deformation measure of the buildings, the sounding programme and the soil laboratory. Knapp was a veteran of the First World War and an army officer and, on the project, he was the go-between the workers and management in the Chicago Subway Works, to complete the ongoing tasks. In addition, he also served as a mentor to Ralph Peck during his career in Chicago.

Years after working together, Peck said he learned as much from Ray Knapp as he did from Terzaghi, not just on soil mechanics, but on how a geotechnical engineer could do something good in an organization.

Another person who influenced Peck's career was Ralph Burke ${ }^{5}$. Burke was chief engineer of many notable projects in Chicago, including the subway, Meigs Field Airport and O'Hare Airport. When he opened his own consulting firm in 1951, he tried to recruit Peck to work with him. Burke employed Peck as a consultant in many of his consultancy projects.

\section{Chicago Subway}

During his period working on the Chicago Subway Project, Ralph Peck made important contributions to the field of geotechnics. Among these contributions we can highlight his participation in the book of soil mechanics Soil Mechanics in Engineering Practice, the development of the observational method and articles written with Terzaghi.

\subsection{Soil Mechanics in Engineering Practice}

In 1948 was published the first edition of the book Soil Mechanics in Engineering Practice, a book written jointly by Terzaghi and Peck and published by John Wiley \& Sons.

In 1943 Terzaghi had already published a book on soil mechanics titled Theoretical Soil Mechanics, also published by John Wiley \& Sons. Cummings contributed to the writing of this book because Terzaghi had asked him to revise several chapters of the book before it was published.

The beginning of the plans to publish the book Soil Mechanics in Engineering Practice started when Terzaghi introduced Peck to Edward P. Hamilton, president of John Wiley \& Sons. Peck and Hamilton happened to both be students

\footnotetext{
${ }^{5}$ Ralph H. Burke (1884-1956). He started at university studying law, which he left to study engineering at MIT, graduating in 1906. The Chicago Subway Project chief engineer and Chicago City engineer responsible for almost all planning projects until 1946 when he formed his own consultancy firm, at the age of 64 years. One of his first commissions was the development and initial construction of O'Hare International Airport in Chicago, which he carried out until his death.
}

of the Rensselaer Polytechnic Institute, which created a certain connection between them. In different meetings between Hamilton and Peck, Hamilton himself encouraged Peck to work, edit and publish a book on elementary soil mechanics, an interest that got Peck excited. However, due to the great influence exerted by Terzaghi on Peck, Peck himself thought that the book should be published under Terzaghi's name; however, Terzaghi replied that "there is no reference in my mind to the need to prepare an elementary textbook" (Dunnicliff and Deere, 1984).

It was not until November 1942 that Terzaghi asked Peck whether he would cooperate with him as a co-author on a book for college students, a proposal that Peck immediately accepted (Dunnicliff and Deere, 1984). Regarding the writing of the book, Peck added the following: "to our surprise, the writing of the book did not go well. Suffice it to say that, even for Terzaghi... the book presented gaps in its application to the most common problems and, if possible, those gaps had to be filled" (Dunnicliff and Deere, 1984).

Finally, the book Soil Mechanics in Engineering Practice was published in 1948 after 7 years of collaboration between Peck and Terzaghi, a collaboration that began during the execution of the work on the Chicago subway. This textbook would immediately become a classic in the bibliography of soil mechanics. This made Ralph Peck famous and in great demand, which he had not enjoyed before.

In some final comments, Terzaghi wrote to Peck that "I value, in a way that I cannot express properly, what it has meant to work with you on this book. Besides all the benefits I could cite, the one that impressed me the most was your personality. I have heard them say that there are people whose passion for truth and perfection eclipses any personal interest. I considered that this was, in large part, a way of speaking until I understood it through our association. It is a pleasure to debate with you, because the argument is always constructive and never personal. Not a lot of people like that. I have learned from your things more important than the mechanics of soils" (Dunnicliff and Deere, 1984).

In the text appears for the first time the term "standard penetration test" (SPT), a term invented by Terzaghi to describe a type of test of dynamic penetration for the geotechnical recognition of ground. The SPT required the use of the instrument developed by Charley Gow in Boston at the beginning of the 1900s.

The success of the book is demonstrated by the several editions that have been published. The second edition was published in 1967, three and a half years after the death of Terzaghi. Both the first and second editions have been translated and published in 17 different languages, more than any other geotechnical engineering text in the twentieth century. A third edition of the book was also published in 1996 in which Gholamreza Pray Mesri participated as author, who currently holds the position of professor of the R. B. Peck Chair in geotechnical engineering at the University of Illinois. 


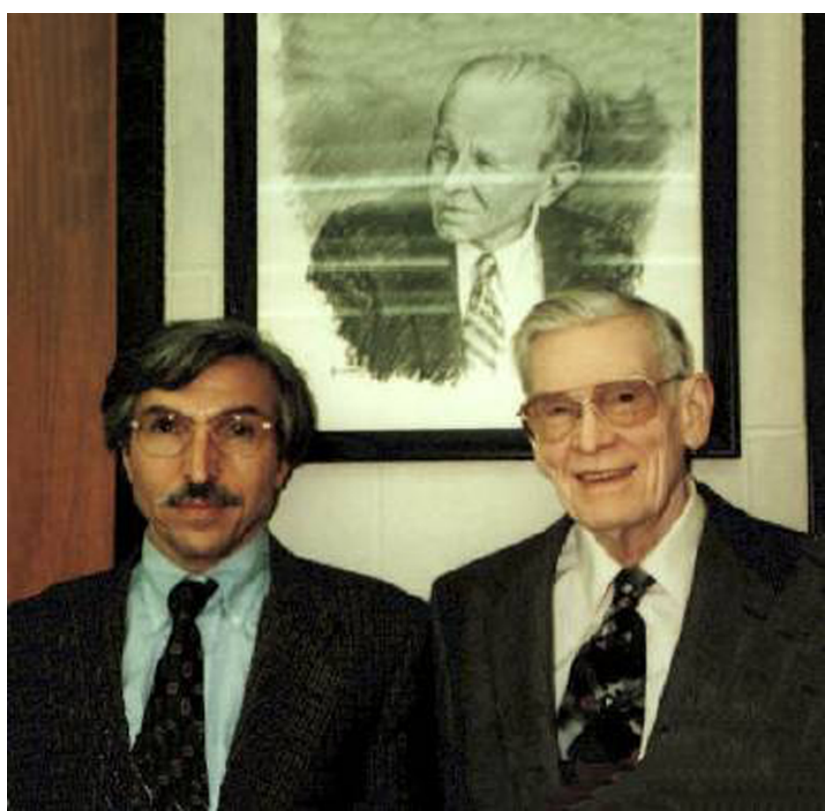

Figure 2. Gholamreza Mesri and Ralph B. Peck in front of a portrait of Terzaghi. Source: Ralph B. Peck Family. All rights reserved.

In addition to his important contribution in the book Soil Mechanics in Engineering Practice, it was not until 1953 that Peck published with John Wiley \& Sons another book titled Foundation Engineering, which he wrote with Thomas Thornburn ${ }^{6}$ and Walter Hanson ${ }^{7}$. This book was immediately adopted as a reference book in more than 50 universities. It was not until 1974 that a second edition of the textbook was published, which consolidated it as a classical text on the subject during the 1980s.

\subsection{Observational method (OM)}

During the Chicago Subway Works with Karl Terzaghi, Peck developed a controversial new constructive technique known as the "Observational Method (OM)" (Peck, 1969), although the initial name of this constructive technique was "Observational or learn-as-you-go procedure" (Dunnicliff and Deere, 1984). The main objective of the OM was to advance the project as it progresses, through a follow-up of soil behaviour during construction. In this way, it is possible to design the structure to the limit of what is possible without reaching a collapse.

${ }^{6}$ Thomas H. Thornburn (1916-1986), civil engineer, professor of civil engineering at the University of Illinois.

${ }^{7}$ Walter E. Hanson (1916-2010), civil engineer, professor of civil engineering at the University of Illinois and founder of Hanson Professional Services Inc. Hanson was fundamentally a structural engineer, but he chose the materials of soils and foundations as postgraduate training. He was the first successor to whom Peck entrusted the undergraduate course Foundation Design.

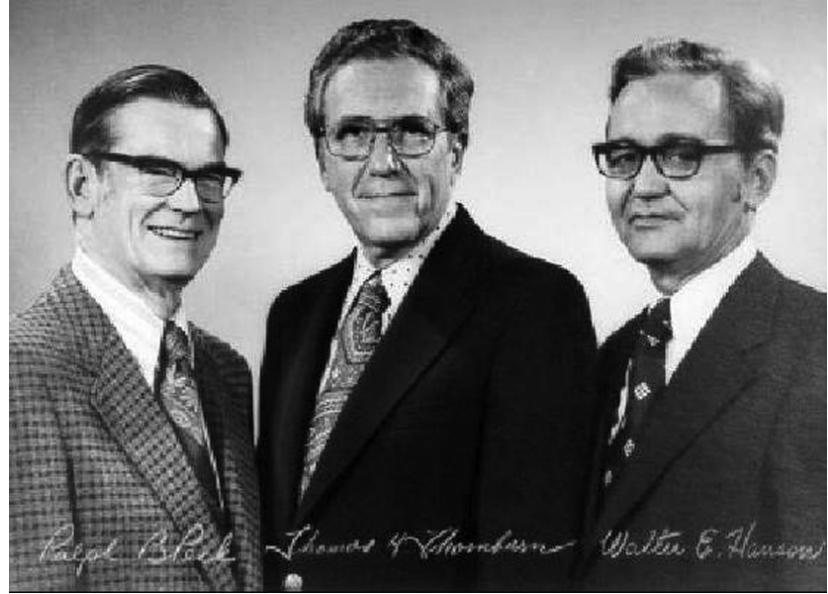

Figure 3. From left to right: Ralph B. Peck, Thomas (Tom) Thornburn and Walter (Walt) Hanson. Source: Ralph B. Peck Family. All rights reserved.

The observational method consists of the following steps, with the order of execution depending on the nature of the terrain and the complexity of the work to be done (Peck, 1969).

- Exploration. It consists in making an accurate enough observation to establish at least the pattern and properties of the deposits, but not necessarily in detail.

- Evaluation. It is based on valuing the most probable conditions during the works, and in turn, the most unfavourable conceivable deviations from the most probable conditions. The evaluation of geological assessment plays an important role.

- Design. A first design is determined based on a working hypothesis to try and predict the behaviour under the most probable conditions.

- Selection. As the construction progresses, the units to be observed are selected, for which are calculated the anticipated values based on the working hypothesis.

- Calculation. The values for the selected units are calculated under the most unfavourable conditions from the data available of the terrain.

- Early selection. Early selection consists in anticipating selecting the actions or modifications of the design for each observed deviation that is predictable, based on the predictions made based on the work hypothesis.

- Measurement. This consists in quantifying the units of work to observe and to evaluate the real working conditions.

- Modification. Finally, the design is readjusted to adapt to the actual working conditions. 
The observational method aids in assessing the behaviour of the earth structure during construction, which can then be modified in accordance with the findings. The observational method was not only used by Peck, but was widely accepted within the profession, although some clients and insurance companies complained about the uncertainties of the OM.

It was not until 1969, when Ralph Peck was asked to give the 9th Rankine Lecture, that he publicly announced his observational method with a paper entitled "Advantages and limitations of the observational method applied to soil mechanics" (Peck, 1969).

Regarding OM, Ralph Peck said that the method was not exempt from traps and limitations and should not be used unless the planner had in mind an action plan for each unfavourable situation that could be detected by the observations. In addition, Peck insisted that the observations should be real, that they reveal the meaning of the phenomenon, and that they should be communicated in such a way as to allow a rapid response without compromising the security of the project. Despite the limitations of OM, Peck claimed that this technique has great potential for saving time and money without sacrificing security.

As for his opinion against OM, Peck explained: "Let nature speak for itself". "There is no better practice than predicting and verifying how subsoil materials behave and adjusting design and constructive procedures based on observations of project development". In other words, OM reflects Peck's belief in the good judgment of engineering, and in sampling and analysing soil behaviour, in clear opposition to the emerging model science and numerical analysis. In fact, according to Peck, modern numerical theory did not adequately consider the variability of terrain conditions: "Theories and calculations are not substitutes for criterion (judgement) but are the basis for a more complete criterion", an opinion which generated some enemies within academic circles.

\subsection{Articles with Terzaghi}

During the advancement of the Chicago Subway Project, Terzaghi and Peck collaborated to prepare a summary report about the construction of the Chicago subway.

Three key papers originated from these reports.

- The first one was written by Terzaghi and was about the lining in tunnels. This article was written for a floor mechanics session sponsored by the ASCE in October 1941 and was taught in Chicago.

- The second one was written by Peck for the same floor mechanics session described in the first article. In this second article, titled "Earth-Pressure Measurements In Open Cuts Chicago Subway", Peck described the distribution of equivalent pressures in an open excavation. In addition, within the second article Peck presented the equivalent pressures for shored excavations in clays that are governed by trapezoidal distribution. This was a breakthrough since in 1857 Rankine land pressure theory predicted a triangular pressure distribution.

- The third article was written by Terzaghi about support in tunnels.

These articles were later published in June 1942 by the ASCE Proceedings and, subsequently, in 1943 by ASCE Discussions. In addition, the third article was also published by the Society of Civil Engineers of Boston.

In addition to all the events mentioned during the Chicago Subway Project, Peck's daughter, Nancy Jane, was also born during the development of this project. Nancy was born in Evergreen Park, Illinois, where Peck lived during these works.

Finally, in May 1942, both the projects of the Chicago Subway Works were closed. The shutdown occurred due to the steel deficit because of the needs of the United States for the Second World War.

\section{University of Illinois}

In addition to all of Peck's work during the Chicago Subway Project, he was also teaching and conducting soil mechanics lectures at the Armour Institute of Technology, both for master students and for active engineers. He also lectured at the University of Illinois, about $320 \mathrm{~km}$ south of Chicago, although he attended this less often than the Armour Institute of Technology.

The closure of the Chicago Subway Works in May 1942 meant that Peck was once again unemployed. It should be noted that several months before the closure, in March 1942, Peck was one of the three finalists considered for the position of chief of the division of soils and foundations of the Corps of Engineers of the Army, for the Waterways Experimental Station (WES), during the Second World War. Peck felt that he could not be the person in charge of the administrative responsibilities that were required, so he let the opportunity pass.

In the same month of May 1942, the University of Illinois offered Peck the position of teaching soil mechanics. Before deciding on the matter, Peck sought the advice of Terzaghi, who told him, with some severity, that he needed "more experience" before he could consider himself a professor of foundation engineering. Considering the advice of Terzaghi, Peck rejected the offer of the University of Illinois, despite the risk of staying unemployed.

In search of the experience that Terzaghi had recommended, Peck accepted consultancy work. During his early years as a professional, most of his consulting work was oriented towards foundations. Among these consultancies we can highlight work done in an industrial district along the southern coast of Michigan and known as the Republic of Steel in Cleveland, Ohio, making facilities for mineral storage. In this consultancy work, Terzaghi was in charge of 
guiding the work and Peck supervised trials and developments.

After these works Peck received the approval of Terzaghi to accept the post of professor that the University of Illinois had offered him 7 months earlier. Thus, in December 1942, Ralph Peck joined the Department of Civil Engineering at the University of Illinois in the town of Urbana Champaign. From this place Peck helped build a model geotechnical engineering programme during the period of expansion that followed the Second World War. After joining the university, Peck devoted much of his life to the college, staying active until his retirement in 1974, combining teaching with consulting and research.

After the Peck family settled in Urbana Champaign Peck's second child, a son, James (Jim) Leroy Peck, was born.

In 1945, Peck became a permanent professor at the University of Illinois, which meant a considerable increase in his salary to USD 5000 annually. Faced with this situation, Terzaghi, who had little respect for university bureaucracy, warned Peck to avoid the committees and then become a dean or university administrator for fear that he might become "useless for the profession of civil engineer." Terzaghi knew Peck's potential in the profession, so he did not want him to spend too much time at the college.

\section{First international work}

After Peck's contributions to the world of geotechnics, both as a consultant and as a professor, and even as a researcher, in January 1950 he got his first job opportunity outside the United States. This work consisted of a consultancy for the design of the Neusa Dam, near Bogotá, Colombia, a consultancy project he conducted with his mentor Albert Cummings of the Raymond Concrete Pile Company.

The Neusa Dam is an earth dam about $40 \mathrm{~m}$ high. The dam was conceived with halloysites clays in its nucleus, but during the works it was decided to change them by another type of less problematic clays. After the visit to the dam that gave rise to this change in design, Cummings delegated Peck to write the report of that visit.

As an anecdote of his first international work, to get his first passport Peck had to show that he was an American citizen by descent, because by birthplace he was not.

\section{Alec W. Skempton and Laurits Bjerrum}

In 1953, Ralph Peck attended the Third International Congress on Soil Mechanics and Foundations Engineering held in Zurich. During this congress, Peck took advantage to meet in person the English engineer Alec Westley Skempton, with whom he had had a professional correspondence since 1948. Skempton was a friend of Terzaghi and familiar with the friendship between Terzaghi and Peck, so he asked Peck for information about the Chicago clays and the New Haven thixotropic clays (soils with geotechnical properties depending on time).

Skempton took the opportunity to introduce Peck to the Dane, Laurits Bjerrum ${ }^{8}$. An anecdote of this meeting is that the mutual presentations and conversations ended at a dinner with Peck, Skempton and Bjerrum, which led to the beginning of a good personal relationship by Peck with these two important engineers of soil mechanics.

Part of the Third International Congress was a visit to the Marmorera earth dam, a well-known dam by Bjerrum for his years of work at the Engineering Research Institute of Hydraulic and Civil Engineering in Zurich.

Referring to Skempton, Peck defined him as physically a great man: "... indeed everything related to his greatness, his smile, his laughter, his voice, his gestures... He never described the big things as simply large, for he was huge. In fact, I added the word 'huge' to my own vocabulary; use it often, and never without thinking of it" (Dunnicliff and Deere, 1984).

As for Bjerrum, the good relationship he had with Peck after the congress resulted in Peck himself visiting the Norwegian NGI in 1959 to participate in the research being carried out on the distribution of pressures of land force in shoring trenches, with Laurits Bjerrum directing the research team. Peck's services were requested due to his experience in the construction of the Chicago Subway, and even agreed that a civil engineer, a collaborator of Peck, move to the NGI to study the programme of measurements and their results. The results of this work were presented in 1961 at the 5th International Congress of Soil Mechanics and Foundations Engineering held in Paris.

Peck and Bjerrum met again professionally in 1964, after the Good Friday earthquake in Alaska. The Corps of Engineers from the Alaska District appointed a group of experts to assist in the work on the landslides associated with the earthquake, especially in connection with the Trans-Alaska Pipeline Transport System. This group of experts was formed by Ralph Peck, Laurits Bjerrum and the American engineer Thomas (Tom) M. Leps (Dunnicliff and Deere, 1984). Later, they also worked together on the Oslo subway, in the controversial work of the Dead Sea Dam, a work that lasted about 6 years, and in the treatments of the terrain to fight the deformations under the Leaning Tower of Pisa, Italy.

\section{Accident in the First Wilson Tunnel}

On 10 July 1954, an accident during the excavation of the First Wilson Tunnel on the island of Oahu, Hawaii, caused

\footnotetext{
${ }^{8}$ Laurits Bjerrum, (Farsö, Denmark, 6 August 1918; London 27 February 1973) civil engineer from the Technical University of Copenhagen in 1941 and in 1952 Doctor from the Eidgenössische Technische Hochschule (E.T.H.) of Zurich. Precursor of soil mechanics in Norway and first director of the Norwegian geotechnical Institute.
} 
the deaths of five workers. The accident originated at $200 \mathrm{~m}$ from the southern entrance. Ralph Peck, who was working as a municipal advisor on that work, was involved in the longest legal process against an American engineer.

After the accident, Peck made a report of the accident. As a result of the report, Peck was harassed by the media, politicians and local engineers who were following his work on drilling of the First Wilson Tunnel. In addition, the contractor of tunnels E. E. Black, infuriated by the statements made by Peck, sued Peck again for USD 1.5 million.

This legal case brought to light that Peck, before the accident occurred, had sent the mayor a letter of resignation because the city decided to keep the original contractor instead of following Peck's own recommendations. The revelation of this letter of resignation further infuriated the contractor, who raised his claim to USD 3 million.

In April 1955, Ralph Peck was removed from a passenger plane and detained because of this lawsuit. Marjorie Truby, Peck's wife, learned of this embarrassing event through the headlines of her local newspaper the following morning. After his arrest began an ordeal for Peck that lasted 3 years until the process was resolved.

During this period, Peck was forced to continue his consultancy work. The team that supported Peck during this difficult process was composed of Karl Terzaghi, his mentor Ralph Burke, Leo Casagrande, Walter Lum (graduate student in soil mechanics with Ralph Fadum at Purdue University, Indiana), Dick Loughney and Joseph V. Hodgson (local attorney in Hawaii).

In particular, it was Ralph Burke who supported Peck most during this process. Burke advised Peck both how to defend himself during the legal process and to develop a repair plan for the First Wilson tunnel, and even arranged for his company engineers to develop the excavation plans and to give Peck permanent support during the 2 nd excavation.

Three years later, the case was finally dismissed, and the city had to pay the legal fees to Peck.

\section{Other work and publications}

In addition to his teaching and the consultancy work mentioned above, Peck also carried out research work and other activities of outstanding consultancy work.

\subsection{Research facet}

At the beginning, his research was mainly financed by the Association of American Railroads (AAR), for whom he carried out numerous advanced investigations.

Throughout his work as an investigator, Peck barely received national support to conduct his investigations. In fact, it was Peck himself who asked for funds to solve specific problems that arose during some of the projects in which he participated. In spite of this, Peck's contribution to research was extended internationally wherever he was asked to Participate.

The limited financial support Peck received for his research probably resulted in Peck's own influence, to a large extent, that many of his students receive financial assistance while working on various design-related projects and the construction of dams, tunnels and highways.

\subsection{Other work}

In addition to the aforementioned work, Peck also participated in the following large-scale projects.

- Metropolitan railway line on the Second Avenue of New York.

- Washington Suburban Railway (The Washington Metropolitan Area Rapid Transit Authority in Washington D.C.).

- San Francisco Suburban Railway System (The Bay Area Rapid Transit System).

- Baltimore Suburban Railway (The Baltimore Rapid Transit System).

- The Los Angeles Suburban Railway (Los Angeles Subway).

- The Alaskan Pipeline System.

- Mica Dam.

- Bennett Dam.

- Churchill Falls.

- James Bay Hydroelectric Dam (the James Bay Project) in Quebec, Canada.

All these projects, and those previously mentioned, resulted in an active life for Peck as a consultant that led him to travel 44 states in the United States and 28 countries on five continents (Albuquerque Journal, 2008).

As the years went by, and especially in the last two decades of his professional work, Peck was frequently called as a member of a consulting committee rather than an individual consultant. Several of these advisory committees were formed to assess the reasons for some major failures in which, in addition to knowledge, there was a need for large accumulated experience and extensive technical standards.

\subsection{Other publications}

In addition to all the aforementioned publications, in 1972 Peck published some rather controversial comments on instrumentation in construction (Peck, 1972), comments that reflected his position in favour of standards and good judgment in the field of engineering. 
Already in 1940, Peck had defended field observations, valuing the instrumentation as a necessary requirement for the proper measurement of the ground. Peck recalled that the instrumentation was eventually accepted after some difficult persuasion, but with the passage of time instrumentation became a technology fashion. Excessive use, however, gave rise to a lack of precision in the design of instruments. Thus, Peck concluded with his well-known expression: "An instrument too often overlooked in our technical world is a human eye connected to a brain of an intelligent human" (Dunnicliff and Deere, 1984).

\section{Retirement}

Peck's last academic stage was a period marked by the recognition of his achievements, interspersed with participation as an outstanding consultant in geotechnical problems.

\subsection{End to his teaching career}

June 1974 coincided with his 62nd birthday, when Ralph Peck withdrew from teaching at the University of Illinois after 32 years as a lecturer. When Peck retired, he became professor emeritus at the University of Illinois. The post of professor in the "R. B. Peck Chair in geotechnical engineering", named by the University of Illinois in recognition of Peck's great teaching dedication at the centre, was occupied by his partner and collaborator Gholamreza Mesri.

In his wide-ranging career as lecturer, Peck became famous among his students for his way of teaching and for making them learn how to think to solve complex real-life problems as case studies, trying to get away from the calculators. No student could leave until they had distilled the essence of the problem and faced it with possible solutions on a sheet of paper. Peck himself said that "If you can't reduce a difficult engineering problem on a sheet of paper, you'll probably never understand".

The next anecdote shows the great demand that Peck's work as a lecturer required. In 1974, already retired, the University of California Berkeley invited Peck during the summer semester to teach a course based on historical cases, with the aim that Berkeley lecturers themselves could continue the course in subsequent Semesters. After completing the course taught by Peck, the faculty of Civil Engineering at the University of California Berkeley cancelled the following courses because the professors themselves recognized that none of them had enough experience for that demanding form of teaching.

Peck's demand was not only recognized by Berkeley professors, but was widely extended by the geotechnical community. Proof of this are the words that the professor of Imperial College, John Burland said in reference to Peck: "He was a brilliant educator who brought the profession to the classroom. His great strength was that he taught from historical cases to distill the essence of the problem. This was a terrible discipline and a lot of people who so learned are still grateful".

Even after his retirement, Peck returned twice a year, as Professor Emeritus, to the University of Illinois to give a series of special lectures on different and varied subjects, from the latest in consultancy to the evolution of the foundations of buildings in Chicago from the nineteenth century.

\subsection{Retirement to Albuquerque}

After Peck retired both he and his wife Marjorie searched for a new place to settle down. In the search for less humid climates in the American west, they considered moving to Denver, where they had lived when young, but the overpopulation and pollution forced them to eventually go to Albuquerque, New Mexico. Thus, both participated in the construction of the home of their dreams in Albuquerque, a home that was completed in 1975.

Despite his retirement to Albuquerque, Peck remained actively pursued by his clients around the world. The prestige that Peck had gained throughout his career made clients always eager to know his opinion. The last project in which Peck worked on was the Rion-Antirion bridge that crosses the gulf of Corinth in Greece.

\subsection{Teton Dam}

On 5 June 1976, the Teton Dam, designed by the United States Bureau of reclamation, failed during its first reservoir filling. The Teton Dam had a height of $135 \mathrm{~m}$ from the foundation to coronation and the rupture caused the death of 14 people and produced losses of more than USD 400 million. Total damage estimates have ranged up to USD 2 billion.

To study this break, an independent committee was formed by Wallace L. Chadwick, who acted as president, Howard A. Coombs, Munson W. Dowd, E. Montford Fucik, R. Keith Hiffinson, Thomas M. Leps, H. Bolton Seed, Arthur Casagrande and Ralph B. Peck. Of this committee Peck said that "In my opinion, the independent committee to review the causes of the Teton Dam failure was an extraordinary example; each member had considerable experience and ability to express it, but through discussion and interaction there was a higher document than could have been written by any of the members of the Committee" (Peck, 1976).

The work to be done by the committee was quite simple, as each member of the committee was in charge of a specific chapter and then dealt with them all together. However, the process for establishing the initial draft was not easy, requiring numerous committee meetings in which both criticism and suggestions came from each and every member of the committee. It was virtually impossible to identify any contribution from a specific member of the committee, with the exception of the process of rupture based on the standards of Casagrande, who also made the original draft on the hy- 
draulic fracture, and the analysis of the finite element rupture carried out by Bolton Seed.

From among all possible chapters, Peck was commissioned to draft chapter 12: causes of the break. In the development of the chapter Peck recognized that it was not possible to know precisely the conditions that gave rise to the first break, so it was assumed that it was a combination of various factors: geological details, deficient compaction, presence of pore pressure, and stress differences in the ground, and because they were unknown they were not, therefore, irrelevant. Regarding the break conditions Peck claimed that "The ruling was caused not because there was some unpredictable fatal combination, but because the many unfavorable circumstances inherent in the situation were not visualized and because adequate protections against these circumstances were not included in the design" (Peck, 1976).

\section{His final years}

Peck's final years were full of stories about the work he had done throughout his career.

In 1996 Peck's wife, Marjorie Elizabeth Truby, died after a long illness.

In August 1997 Ralph Peck was invited to give the keynote address at the opening luncheon of the first geo-institute of the ASCE in Logan, Utah. In this speech, Peck took the opportunity to dedicate a few words to Karl Terzaghi, by criticizing the university education system: "If universities allow professors to teach foundation engineering to those who have never designed foundations, we can't expect much from our graduates". These words reflected the experience that Peck had to gain, on the advice of Terzaghi, before teaching at the University of Illinois, which helped him a lot in his teaching career.

This fact is also reflected in other words that in his day Terzaghi dedicated to Peck: "I express the hope that Ralph will succeed where I have failed and that he can educate generations of foundation engineers to retain their common sense and sense of proportion" (Lacasse, 2000).

In 1999, the ASCE created the award Ralph B. Peck to recognize the merits of a person of extraordinary contribution to the profession of geotechnical engineering through reasoned and carefully investigated publications of historical background or cases, or of publications of recommended practices or design methodologies based on background or historical case evaluation.

In May 2000 the Norwegian Geotechnical Institute (NGI) founded the Ralph Peck Library in addition to the Terzaghi Library.

Finally, Ralph B. Peck died of cardiac congestion on 18 February 2008 at his home in Albuquerque, New Mexico, United States (Peck Young, 2008).

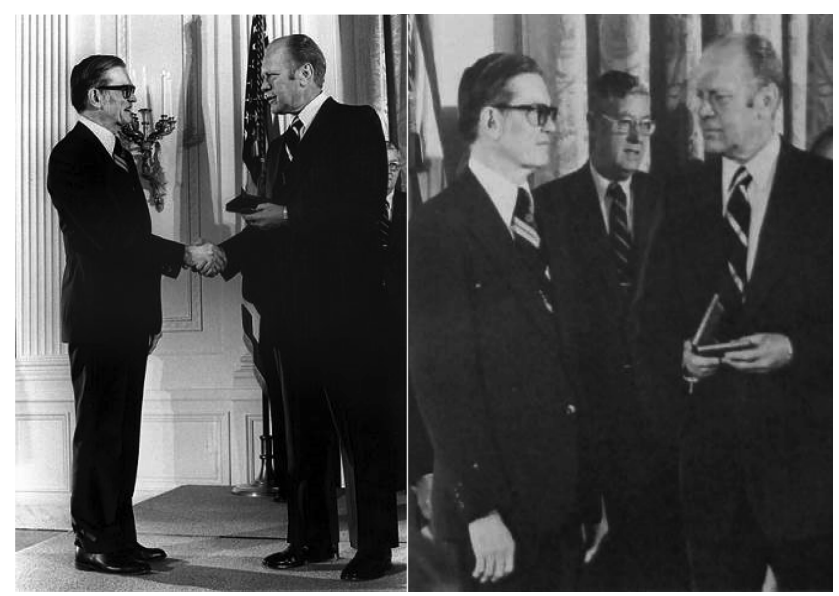

Figure 4. Ralph B. Peck receiving the National Medal of Science from the hands of President Gerald R. Ford on 18 September 1975. Available from the Peck legacy website (http://peck.geoengineer. org, last access: April 2018).

\section{Awards and recognitions}

Throughout his life, Peck won numerous awards and recognition for his career, which are listed below.

- In 1944 he received the Norman Medal for his article "Earth-Pressure measurements in Open Cuts, Chicago (Ill.) Subway"; at the age of 31, he was the youngest person to have received this award alone.

- In 1965 Peck was awarded with the Wellington prize by the ASCE, for his articles, published the previous year, relating to foundations of means of transport.

- In 1969 Peck was honoured by the Institution of Civil Engineers (ICE) UK to give the 9th Rankine Lecture.

- In 1969 he received the Karl Terzaghi Award from the ASCE, to an "author of continuous and exceptional contributions to the knowledge in the fields of soil mechanics and ground and subsoil Engineering and its construction in the United States, which he has shown in his publications both for the matter in question as for technical merits."

- In 1973 he received the Army Civil Service Medal in recognition of his contributions as a consultant to the Corps of Engineers between July 1954 and December 1972.

- In 1973 he received the Moles Award as a non-member for his contribution to tunnel engineering and technology.

- In September 1974, on the proposal of Linus Pauling, he was awarded the National Medal of Sciences of the same year. 
As an anecdote of this prestigious award, Peck should have received this award from the President of the United States of the same year, which in 1974 was Richard Nixon, but who refused to deliver it in person given the political opposition by Pauling. So, it was not until September 1975 that Ralph Peck received the National Medal ${ }^{9}$ of Science at the White House, but from the hands of the next President of the United States, Gerald R. Ford.

- In 1976 the Washington Medal from the ASCE.

- In 1978 the award for distinguished services from the University of Illinois.

- In 1978 he was named Doctor Honoris causa by the University of Laval, Quebec, Canada.

- In 1980 he received recognition of his friendship with Laurits Bjerrum when the Norwegian Geotechnical Institute (NGI) offered him the Bjerrum Memorial Lecture, the first to a non-member of the NGI to receive such honor (Lacasse, 2000).

- In 1988 the Rickey Medal from the ASCE.

- In 1988 the John Fritz Medal.

- In 1999 he was named Doctor honoris causa by the Rensselaer Polytechnic Institute, Troy, New York, where he had graduated as an engineer and where he had completed his doctorate.

- In 2000 he was named First Hero of the geo-institute of the ASCE.

- In 2005 he received the Outstanding Civil Engineering Award from the ASCE for his work on the project of the Rion-Antirion Bridge over the Gulf of Corinth, Greece, which was the only time that this award was given to a work outside the United States.

\section{Societies}

During his career, Ralph Peck belonged to several societies, of which we mention the following.

- Member of the National Academy of Engineering.

- Member of the American Academy of Arts and Sciences.

\footnotetext{
${ }^{9}$ The mention that accompanies the medal says that "by his development of the science and art of the underground engineering, combining the contribution of the geological sciences and the mechanics of soils with the practice of the art of design of the foundations". Ralph Peck is the only geotechnical engineer to have received this honour.
}

- President of the International Society of Soil Mechanics and known Foundation Engineering (ISSMFE) from 1969 to 1973 , in which he participated actively.

12

\section{Conclusions}

Ralph B. Peck's story begins with little economic hardship. American by descent and Canadian by birth, Peck was the only child of a middle-class family, with his mother working as a teacher and his father as a railroad bridge engineer.

In his childhood, Peck was a sickly boy, but he lived to be 95 years, one of the longest-lived 20th century geotechnical engineers.

The influence of his family was very important, both in his education and in human values, which conditioned his character.

Throughout his life Peck was a religious person, influenced by his parents especially by two of his grandparents who were missionaries. This meant that during Peck's childhood his social life was centered on Christian groups. In fact, it was in his Christian motivational group of the Denver Presbyterian Church that he met Marjorie Elizabeth Truby, who would later be his wife and with whom he had two children: Nancy J. Peck and James L. Peck.

Peck was always a balanced, prudent person, of exceptional integrity and defendant character. Proof of this is when he decided to study soil mechanics at Harvard University, where Arthur Casagrande was a lecturer. Peck had to insist greatly on joining as soon as possible a course that had already begun. Finally, Peck was accepted and was able to join as a listener to bypass the administrative bureaucracy. Peck described this event verbatim in 1984: "He wrote to me (Casagrande) politely saying that it would be a great disadvantage to join his group when they had completed more than half of the syllabus, and recommended that I wait until the next fall" (...) "when I arrived and called his office, he greeted me politely and made every effort to know if my wife and I were conveniently housed in Cambridge and never referred to the drawbacks that my mid-course incorporation should have caused him" (Peck, 1993).

However, this situation is not the only one in which Peck demonstrated his character. When they offered him a job he knew how to deal with the situation and make important decisions. Proof of this is that after having sent Casagrande his wishes to join Harvard he got the job offer he was hoping to work as a bridge designer for Waddell \& Hardesty, but he rejected it. Another proof of Peck's seriousness and integrity was when in 1942 he rejected the position for Chief of the Land and Foundation division of the Army Corps of Engineers for WES because he was not entirely qualified for it.

From the moment Peck left for Harvard to study soil mechanics, his professional career shifted in a radical way. This was the first step towards the world of soil mechanics of one of the greatest geotechnical engineers of the twentieth cen- 
tury, Ralph B. Peck. It did not take long for Peck to stand out at Harvard due to his qualities and his determination, which led him to work as an assistant of the chair and collaborate with Casagrande, which later resulted in working with Terzaghi on the Chicago Subway Works. After Harvard, the Chicago Subway Works were the final factor in Peck devoting himself professionally to the world of geotechnics. In these works, Peck began his professional development as a researcher and as a consultant.

One of the great contributions to the world of geotechnics that Peck made during the works of Chicago was the publication of the book Soil Mechanics in Engineering Practice in 1948 and the articles written with Terzaghi. There were two more editions of the book and Peck also received many prizes for his articles. These contributions gave Peck good recognition and many job offers. Another great contribution from the Chicago Subway was the development of the observational method (OM), which faithfully represents Peck's character in engineering that required knowledge of the situation and the way of acting in the face of problems. The method was not accepted by the entire geotechnical community; even the builders themselves were not reliable. OM was not a valid method for everyone, only the big ones like Peck who could handle such a simple yet so complicated method.

In addition to the great contributions that Peck made as a consultant and researcher, another field in which he excelled was his work as a lecturer at the University of Illinois. For 32 years Peck was committed to this university in the teaching of soil mechanics. His character, as in everything else, was overwhelming. He based his teachings on the study of historical cases, looking for his students to learn and understand the concept behind each design. Both professors and their students recognized the dedication and great demand that Peck had as a teacher. After his retirement from the teaching world, the University of Illinois did not hesitate to appoint him professor emeritus and to create the "R. B. Peck Chair" in geotechnical engineering "for his great career in the University".

Finally, not only do we have to assess all the work that Peck did throughout his professional career towards the world of geotechnics, we also have to assess his relations with the rest of the most important geotechnical ideas of the time and their respective influences. The one who most influenced Peck was by far Karl Terzaghi. From the works on the Chicago subway was forged a good relationship between both, so Peck always had professional and personal support on behalf of Terzaghi. In addition, Terzaghi held always an important personal influence over Peck.

Another of the most important geotechnical engineers who had a lot of influence on Peck was Laurits Bjerrum. After meeting in person during the 3rd International Congress of Soil Mechanics and Foundations Engineering held in Zurich, they established a very good relationship that led them to work together several times.
In addition to Bjerrum and Terzaghi, it is worth mentioning the work of people like Albert E. Cummings and Ralph Burke, who helped Peck a lot during the Chicago Subway Works. Also, Arthur Casagrande for his teachings at Harvard and the good relationship he maintained with Peck, which resulted in Peck being assigned as an assistant to Terzaghi in Chicago and Alec W. Skempton, whom he also met in the 3rd International Congress of Soil Mechanics and foundation engineering and with whom he also had a good relationship.

Data availability. The underlying information and research data of this paper can be found in the references. The doctoral thesis of Llorente (2015) is also useful.

Author contributions. All the authors have contributed to the work. GGL was the author of the original doctoral thesis; ALG and RGA have written and reviewed the manuscript and have translated it into English.

Competing interests. The authors declare that they have no conflict of interest.

Acknowledgements. We thank the anonymous referees for their useful suggestions.

Edited by: Giovanni P. Gregori

Reviewed by: three anonymous referees

\section{References}

Albuquerque Journal: Obituary for Peck, ABQJournal.com, Online Edition of the Albuquerque Journal, 2008.

Dunnicliff, J. and Deere, D. U.: Judgment in geotechnical engineering. The professional legacy of Ralph B. Peck, Wiley Interscience Publication, John Wiley \& Sons, New York, USA, 1984.

Hirschfeld, R. C. and Poulos, S. J.: Embankment-Dam Engineering, Casagrande Volume, John Willey and Sons, New York, USA, 1974.

Lacasse, S.: The Norwegian Connection, Ralph B. Peck. engineer, educator, a man of judgment, Norwegian Geotechnical Institute, Norway, 207, 2000.

Llorente, G. G.: Contribución al conocimiento de los primeros geotécnicos del siglo XX, Universidad politécnica de Madrid, Madrid, 2015.

Nicolau, J. and Puig de la Bellacasa, N.: The irrigation works in the United States, Revista de Obras Públicas, 1742, 61-67, 1909.

Peck, R. B.: Advantages and limitations of the observational method in applied soil mechanics, Ninth Rankine Lecture, Géotechnique, 19, 171-187, 1969.

Peck, R. B.: Observation and instrumentation: some elementary considerations, Highway Focus, U.S. Department of Transport, Federal Highway Administration, 4, 1-5, 1972. 
Peck, R. B.: Earth dam, Report to U.S. Department of the Interior and State of Idaho, Failure of Teton Dam, Idaho falls, Idaho, 1976.

Peck, R. B.: The coming of age of soil mechanics: 1920-1970, The first Spencer J. Buchanan Lecture, Texas A\&M University, 1993.
Peck Young, N.: Obituary Ralph B. Peck 1912-2008, available at: http://research.engr.oregonstate.edu/usucger/Obituaries/ Peck_Ralph.pdf (last access: 29 January 2019), 2008. 